\section{Real-Time Assay of Tryptase Release from Human Umbilical Cord Blood-Derived Mast Cells}

\author{
BioTechniques 34:910-914 (May 2003)
}

Mast cells are the central mediating cells of allergic reactions responding via the high-affinity IgE receptor (FceRI) through binding of $\operatorname{IgE}$ and specific antigen (1). This activation leads to the release of preformed mediators stored in secretory granules (such as histamine, $\alpha$ and $\beta$ tryptases, and chymase) as well as to the de novo synthesis of leukotrienes and prostaglandins and the production and release of various cytokines and chemokines (1).

The monitoring of mediator release has been used in the past as a direct measurement of mast cell activation. In particular, assays to detect histamine have long been the standard used for studies of mast cell function (2-6). In addition, although the release of the mast cell protease tryptase has been used to monitor mast cell activation, those assays describe a multi-step technique in which tryptase levels are determined at a given endpoint after removal of cells $(7,8)$. We report the development of a real-time assay for mast cell tryptase release from small numbers of cells $\left(10^{4}\right.$ cells/assay point). This assay measures the release of tryptase from cells real-time and does not require manipulation of the cells other than incubation with appropriate stimuli.

To propagate human cord blood-derived mast cells (CMBCs), human umbilical cord blood mononuclear progenitors (Poeitic Technologies, Gaithersburg, MD, USA) were placed into culture medium (RPMI/10\% FBS; Invitrogen, Carlsbad, CA, USA) in the presence of stem cell factor and IL-6 (R\&D Systems, Minneapolis, MN, USA), both at $100 \mathrm{ng} / \mathrm{mL}$, at a density of $1 \times 10^{6}$ cells $/ \mathrm{mL}$ (modification of Reference 9). One half of the culture medium was changed each week. After five weeks, IL-4 (R\&D Systems) was introduced into the medium at 100 $\mathrm{ng} / \mathrm{mL}$. Cultures were continued for eight weeks and evaluated by staining with Toluidine blue dye. Cells used for functional assays were a minimum of 90\% Toluidine blue positive.

Eight- to ten-week-old CBMCs were lysed by three rounds of freeze/ thaw, and the lysate was diluted in tryptase assay buffer (100 mM Tris$\mathrm{HCl}, \mathrm{pH} 8.0,100 \mathrm{mM} \mathrm{NaCl})$ in a final volume of $50 \mu \mathrm{L}$ and placed in the wells of a 96-well plate (Pierce Chemical, Rockford, IL, USA). An additional $50 \mu \mathrm{L}$ of buffer alone or buffer containing protease inhibitors (all from Sigma St. Louis, MO, USA) was added to each well. A final 50 $\mu \mathrm{L}$ substrate [tosyl-glypro-lys-p-nitroanilide (10) (Sigma), $25 \mathrm{mM}$ stock in $100 \%$ DMSO] in buffer was added to a final concentration of $500 \mu \mathrm{M}$, and the plate was immediately read in a plate reader (Molecular Devices, Sunnyvale, CA, USA) at 410 $\mathrm{nm}$ in the kinetic mode for $15 \mathrm{~min}$ with data collection every $30 \mathrm{~s}$. Enzyme activity was determined as the rate of change of $\mathrm{A}$ due to cleavage of the substrate (velocity) and reported as $\mathrm{mOD} / \mathrm{min}$. The proteolytic activity present in varying numbers of cells against a serine protease substrate (tosyl-gly-pro-lys-p-nitro anilide) is shown in Figure 1 along with the activity of $5 \mathrm{nM}$ rh- $\beta$-tryptase (Promega, Madison, WI, USA). Proteolytic activity above background could be detected from as few as 100 cells and was linear with cell number through the range tested $\left(r^{2}=0.99\right)$. This protease was inhibited by serine protease inhibitors (antipain, BABIM, benzamidine, leupeptin, and TLCK) and lactoferrin (which inhibits tryptase by competing for heparin) (data not shown) (11). Cysteine protease inhibitors (aprotinin, pepstatin, and TPCK) were not effective (data not shown). This pattern of inhibition suggests that the proteolytic activity being measured is indeed that of tryptase.

To assay the real-time release of tryptase, CBMCs were sensitized for $24 \mathrm{~h}$ or longer in the presence of varying concentrations of human IgE (Biodesign, Saco, ME, USA). Before use, the cells were pelleted for 4 min at $1000 \times g$ and resuspended in RPMI at 2 $\times 10^{5}$ cells $/ \mathrm{mL}$. Fifty microliters of cells (approximately 10000 cells/well) were added to each well of a 96-well plate. Either $50 \mu \mathrm{L}$ of buffer or buffer containing compounds to be tested was added to each well, and the plate was

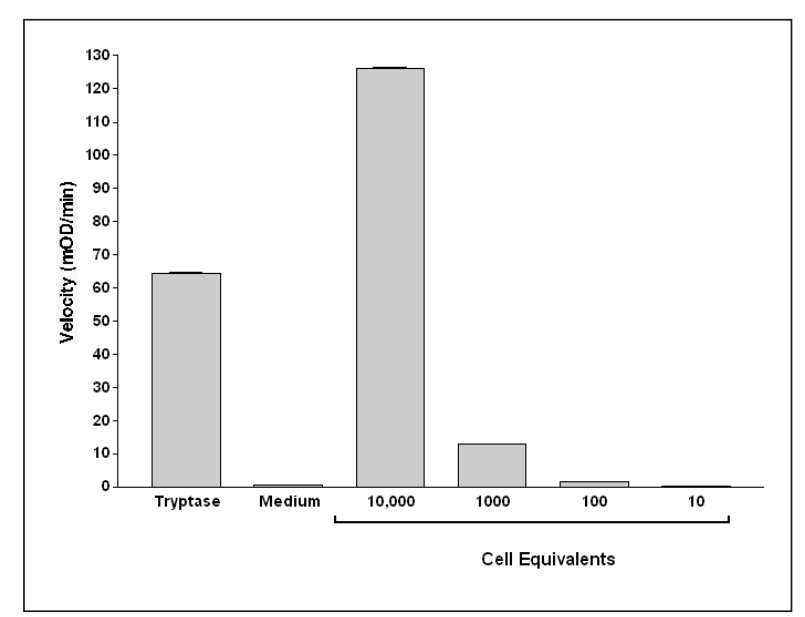

Figure 1. Proteolytic activity released from CBMCs by freeze/thaw. Various numbers of CBMCs were subjected to three rounds of freeze/thaw, and the cell debris was pelleted. The supernatant was tested for protealytic activity against $500 \mu \mathrm{M}$ tosyl-gly-pro-lys-para-nitroanilide. rh- $\beta$-tryptase was run at $5 \mathrm{nM}$ final concentration. Enzyme activity is indicated as change in $\mathrm{A}(\mathrm{mOD} / \mathrm{min})$. Values are presented as $\overline{\mathrm{X}} \pm$ SEM of three independent experiments performed in triplicate. 


\section{Benchmarks}

incubated at $37^{\circ} \mathrm{C}$ for $30 \mathrm{~min}$. To activate cells, $50 \mu \mathrm{L}$ of buffer containing substrate as above along with varying concentrations of sheep anti-human IgE (Biodesign) were added to each well, and the plate was immediately read in a plate reader at $410 \mathrm{~nm}$ in the kinetic mode for $45 \mathrm{~min}$ with data collection every $30 \mathrm{~s}$. Figure 2 shows the time-dependent increase in A due to the release of tryptase after activation of the cells by anti-IgE, as well as control cells with no anti-IgE stimulation. In stimulated cells, there is an initial lag of 7-10 min (likely due to the time it takes to accumulate sufficient tryptase) and a plateau occurring at approximately 30 min (due to limiting substrate). The velocity of the change in $\mathrm{A}(\mathrm{mOD} / \mathrm{min})$ within the linear portion of the curve (from about 12 min through about 22 min) was used in subsequent analyses as the measure of mast cell tryptase release. The observed increase in $\mathrm{A}$ in the unstimulated cells is due to the small

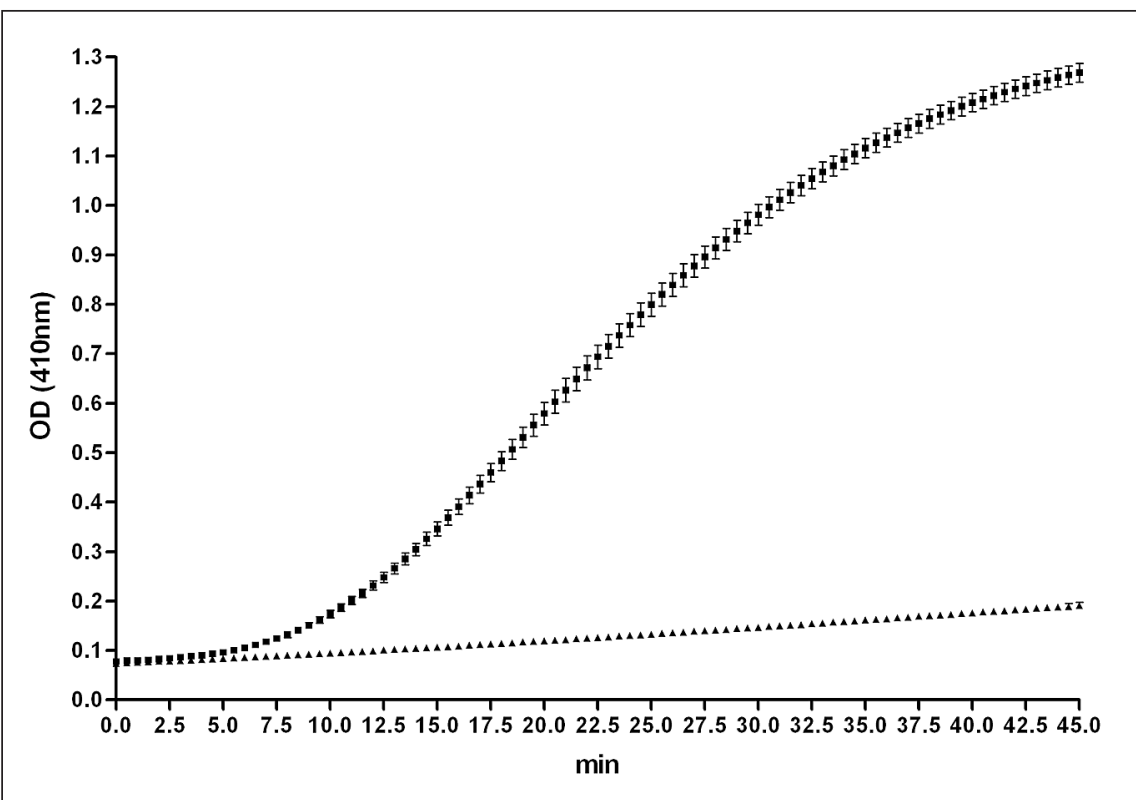

Figure 2. Time course of tryptase release from CBMCs activated through the FceRI receptor. CBMCs were passively sensitized with $1 \mu \mathrm{g} / \mathrm{mL}$ IgE for $24 \mathrm{~h}$. Cells were then activated by the addition of $10 \mu \mathrm{g} / \mathrm{mL}$ anti-IgE in the presence of $500 \mu \mathrm{M}$ tosyl-gly-pro-lys-para-nitroanilide. The graph shows the A reading at 30 -s intervals through a 45 -min time course and is a single representative experiment (of $>50$ ) with triplicate determinations. ( $\mathbf{I g E} / \mathrm{anti}-\mathrm{IgE}, \boldsymbol{\Delta}$ IgE alone). Error bars indicate SEM.

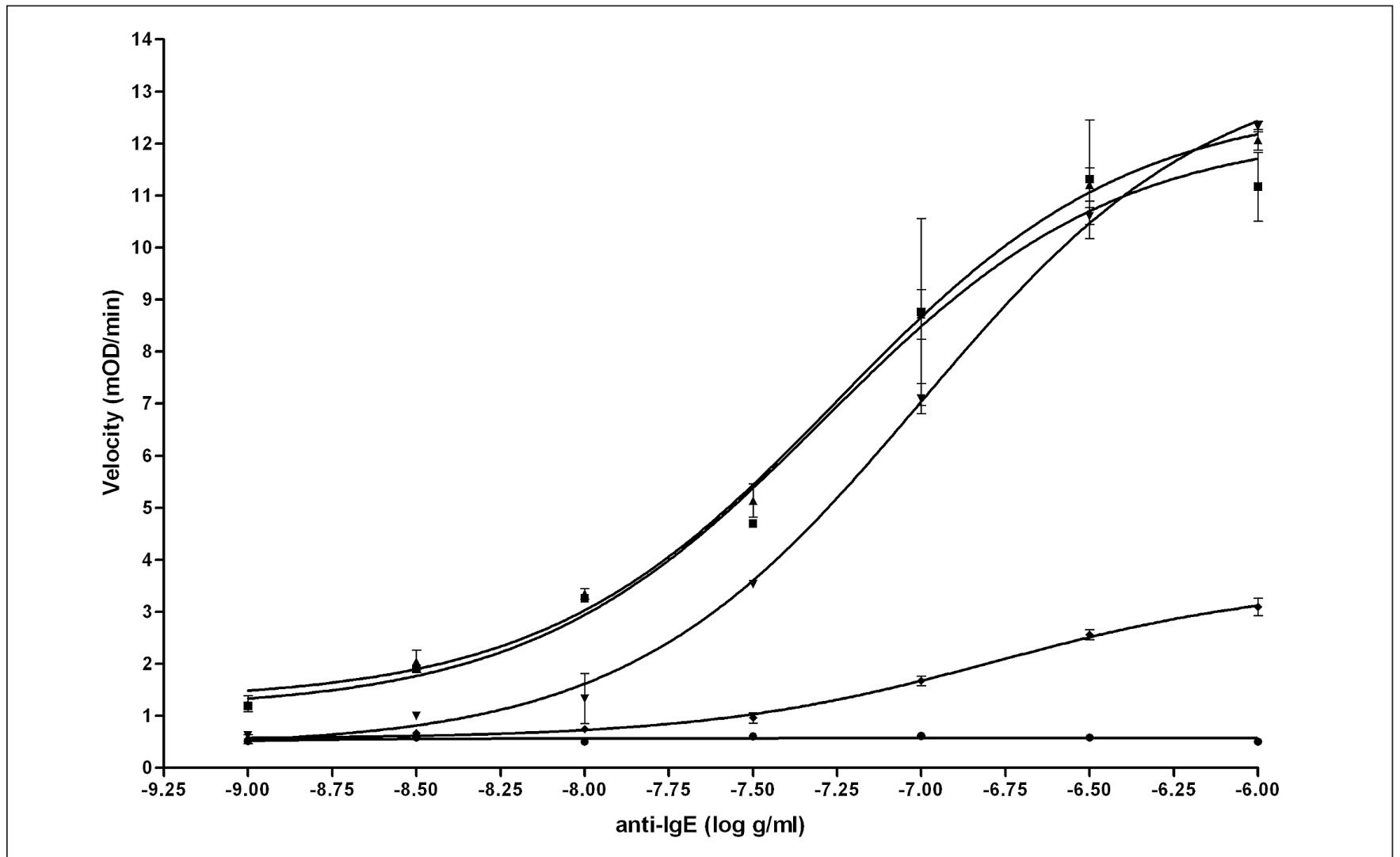

Figure 3. Tryptase release is dependent on IgE and anti-IgE concentration. CBMCs were passively sensitized for $24 \mathrm{~h}$ with various concentrations of IgE. Cells were activated (with multiple doses of anti-IgE, in triplicate), and tryptase release was monitored as indicated in the Materials and Methods section. The graph shows the velocity $(\mathrm{mOD} / \mathrm{min})$ of substrate cleavage as a function of anti-IgE concentration and is representative of six individual experiments. ( 0.0001 $\mu \mathrm{g} / \mathrm{mL}$ IgE; $\bullet 0.001 \mu \mathrm{g} / \mathrm{mL}$ IgE; $; 0.01 \mu \mathrm{g} / \mathrm{mL}$ IgE; $0.1 \mu \mathrm{g} / \mathrm{mL}$ IgE; $\boldsymbol{\wedge} 1 \mu \mathrm{g} / \mathrm{mL}$ IgE). Error bars indicate SEM. 


\section{Benchmarks}

amount of tryptase that is spontaneously released from cells.

Figure 3 shows dose responses of tryptase release by anti-IgE at various IgE concentrations. Maximal activation of the cells occurred with $0.1 \mu \mathrm{g} / \mathrm{mL}$ $\operatorname{IgE}$ with no detectable activation at $0.0001 \mu \mathrm{g} / \mathrm{mL} \operatorname{IgE}$ (Figure 3). The $\mathrm{EC}_{50}$ values for anti-IgE were $51 \pm 15$, $56 \pm 7.3,145 \pm 60$, and $167 \pm 43$ $\mathrm{ng} / \mathrm{mL}$, respectively, for $1,0.1,0.01$, and $0.001 \mu \mathrm{g} / \mathrm{mL}$ IgE (Figure 3). When the data were analyzed in a reciprocal manner, the $\mathrm{EC}_{50}$ values for $\mathrm{IgE}$ were $1.7 \pm 0.3,2.3 \pm 0.4,3.4 \pm 0.3,5.1 \pm 0.8$, $7.9 \pm 1.8,17.6 \pm 3.2$, and $26 \pm 7.8$ $\mathrm{ng} / \mathrm{mL}$, respectively, for $10,3,1,0.3$, $0.1,0.03$, and $0.01 \mu \mathrm{g} / \mathrm{mL}$ anti-IgE.

A real-time tryptase release assay has been developed. The profile of inhibition of the proteolytic activity released by these cells is consistent with tryptase activity. Tryptase is released by activation of FceRI in a time- and dosedependent manner (Figures 2 and 3). This homogeneous real-time assay requires small numbers of cells, few processing steps, and offers the possibility of high-throughput screening because it is formatted in 96 wells. In addition, this assay allows for the simultaneous identification of both inhibitors and activators of mast cells without alteration of the assay format. The initial lag in activity (Figure 2) allows for the identification of activators when compounds are pre-incubated with cells. Using this real-time assay, the $\mathrm{EC}_{50}$ values for both $\operatorname{IgE}$ and anti-IgE for release of tryptase from CBMCs were determined. Additionally, the maximal amount of tryptase released through FceRI was compared with that released by calcium ionophore (data not shown). These amounts were equivalent, which is consistent with previous studies (12) in which the percent histamine release through FceRI was found to be $100 \%$ of that released by ionophore from cells cultured in IL-4. The amount of tryptase released in our studies was typically $10 \%-20 \%$ of total tryptase consistent with $10 \%-20 \%$ histamine release from the same cultures. In addition, this assay has been used to examine tryptase release mediated by endothelin-1, platelet activating factor, phorbol ester, and ATP (data not shown). This methodology should also be applicable to mast cells isolated from other species; however, the protease profile of these mast cells will have to be characterized. This assay will be useful to screen for modulators of tryptase release from CBMCs and will allow the identification of both inducers and inhibitors of release.

\section{REFERENCES}

1.Yong, L.C.J. 1997. The mast cell: origin, morphology, distribution, and function. Exp. Toxic. Pathol. 49:409-424.

2.Lichtenstein, L.M. and A.G. Osler. 1964 Studies on the mechanisms of hypersensitivity phenomena IX. Histamine release from human leukocytes by ragweed pollen antigen. J. Exp. Med. 120:507-530

3.Morel, A.M. and M.A. Delaage. 1988. Immunoanalysis of histamine through a novel chemical derivatization. J. Allergy Clin. Immunol. 82:646-654.

4.Bruce, C., R. Weatherstone, A. Seaton, and W.H. Taylor. 1976. Histamine levels in plasma, blood, and urine in severe asthma, and the effect of coricosteroid treatment. Thorax 31:724-729.

5.Bhat, K.N., C.M. Arroyave, S.R. Marney, D.D. Stevenson, and E.M. Tan. 1976. Plasma histamine changes during provoked bronchospasm in asthmatic patients. J. Allergy Clin. Immunol. 58:647-656.

6.Erger, R.A. and T.B. Casale. 1992. Comparison of methodologies to measure human lung histamine. J. Immunol. Methods 31:115-121.

7.Lavens, S.E., D. Proud, and J.A. Warner. 1993. A sensitive colorimetric assay for the release of tryptase from human lung mast cells in vitro. J. Immunol. Methods 166:93-102.

8.Schwartz, L.B., T.R. Bradford, C. Rouse, A.M. Irani, G. Rasp, J.K. Van der Zwan, and P.W. Van der Linden. 1994. Development of a new, more sensitive immunoassay for human tryptase: use in systemic anaphylaxis. J. Clin. Immunol. 14:190-204.

9.Nilsson, G. and K. Nilsson. 1995. Effects of interleukin (IL)-13 on immediate-early response gene expression, phenotype and differentiation of human mast cells. Comparison with IL-4. Eur. J. Immunol. 25:870-873.

10.Caughey, G.H., W.W. Raymond, E. Bacci, R.J. Lombardy, and R.R. Tidwell. 1993 Bis(5-amidino-2-benzimidazolyl)methane and related amidines are potent, reversible inhibitors of mast cell tryptase. J. Pharm. Exp. Ther. 264:676-682

11.EIrod, K.C., W.R. Moore, W.M. Abraham, and R.D. Tanaka. 1997. Lactoferrin, a potent tryptase inhibitor, abolishes late-phase airway responses in allergric sheep. Am. J. Respir. Crit. Care Med. 156:375-381.

12. Toru, H., R. Pawankar, C. Ra, J. Yata, and T. Nakahata. 1998. Human mast cells produce IL-13 by high-affinity IgE receptor cross-linking: enhanced IL-13 production by IL-4-primed human mast cells. J. Allergy Clin. Immunol. 102:491-502.
Address correspondence to Dr. Scott Greenfeder, Schering-Plough Research Institute, 2015 Galloping Hill Rd. MS-1600, Kenilworth, NJ 07033, USA. e-mail: scott.greenfeder@spcorp.com

Received 18 November 2002; accepted 14 February 2003.

S. Greenfeder, H. Gilchrest, B. Cheewatrakoolpong, S. Eckel, M. Billah, R.W. Egan, and

\section{J.C. Anthes}

Schering-Plough Research

Institute

Kenilworth, NJ, USA

\section{Double-Color Fluores- cence In Situ Hybridiza- tion with RNA Probes}

BioTechniques 34:914-918 (May 2003)

In situ hybridization is a useful tool for localization and partial quantification of gene expression. However, the method is costly and laborious, especially when used to measure the expression of multiple genes. Most previously reported protocols for doublelabeled fluorescence probes involve DNA probe labeling $(1,2)$. The disadvantages of using DNA probes are lower sensitivity and higher background signals. Some methods for double-labeled RNA probes have also been reported, but most involve radioactive probes $(3,4)$. Here we report the development of a unique method of doublecolor fluorescence in situ hybridization (FISH) using RNA probes.

Previous studies have indicated the expression of specific isoforms of sulfonylurea receptors in subpopulations of dopamine-containing cells of the substantia nigra (5). We took advantage of this information to demonstrate the 